Article

\title{
Images of Authentic Muslim Selves: Gendered Moralities and Constructions of Arab Others in Contemporary Indonesia
}

\author{
Mirjam Lücking ${ }^{1, *}$ and Evi Eliyanah ${ }^{2, *}$ \\ 1 Department of Social and Cultural Anthropology, University of Freiburg, Breisgau, Fahnenbergplatz 79085, \\ Germany \\ 2 School of Culture History and Language, The Australian National University, Canberra, ACT 0200, Australia \\ * Correspondence: mirjam.luecking@ethno.uni-freiburg.de (M.L.); evi.eliyanah@anu.edu.au (E.E.)
}

Received: 30 June 2017; Accepted: 29 August 2017; Published: 3 September 2017

\begin{abstract}
In contemporary Indonesia, Muslims increasingly define themselves by othering fellow Muslims, including Arab Muslims. This article examines how Indonesian Muslims, who have traveled to and/or resided in the Middle East, construct their social identities in relation to Arab others. Ethnographic research with labor migrants and pilgrims, and a cultural analysis of cinematic representations of Indonesian students in Cairo, show that conceptions of gendered moralities feature strongly in the ways in which these particular Indonesian Muslims define their authentic Muslim selves, as distinct from Arab others. They attribute ideal male and female characteristic features to Asian Islamic identities, while they portray objectionable ones as Arab culture. This implies that self-representations play a crucial role in the ways in which Indonesian Muslims relate to a region, culture and people long viewed as the "center" of Islamic culture. The representations of Arab others and Indonesian selves eventually lead to contestations of religious authenticity and social class.
\end{abstract}

Keywords: gender; moralities; mobilities; othering; Indonesian Muslims; Arab Others; social identity; Islamization; authenticity

\section{Introduction}

Indonesia-like other Muslim regions in Asia and Africa-is considered to be at the "Islamic periphery" because of its remoteness to the region where Islam was revealed. For Muslims in these "peripheral" regions, the question to what extent Arab culture and customs are part and parcel of authentic Islamic lifestyles appears to be more topical than ever in the post 9/11 era. While some Indonesians promote "Arab" Islamic traditions as purer versions of Islam, others denounce them as cultural derivations from the "true" teachings of Islam. Between these two standpoints are shades of grey, and religious authenticity is the subject of controversial debate in Indonesia.

Gender is a prominent category in these debates. By analyzing how Indonesian Muslims engage with ideas of religious authenticity in relation to Arab others, this article contributes to an understanding of the complex contestation over authentic Islamic lifestyles in contemporary Indonesia, in particular in contexts of spatial mobility to the Middle East. We argue that in these mobile contexts, gendered moralities - as conceptions of what constitutes good Muslim men and women-are central to images of authentic Muslim selves. As the conception of gendered moralities originates from Indonesians' own culture and is represented as superior to Arab gender features, the established concepts of center and periphery in defining authentic Islamic lifestyle crumble. This implies that socially belonging to the domestic context plays a crucial role in the ways in which Indonesian Muslims relate to a region and people beyond Indonesia, including the Middle East as the so-called center of Islamic cultures. 
Pilgrimages to the holy sites in Mecca and Medina, working opportunities and education are the three most widespread reasons for Indonesians' journeys to the Middle East. In this context, spatial mobility is intertwined with the construction of social identities. Renegotiations of social identity happen through the representations of self and other in the course of these travels and become relevant even for those who stay put. Indonesian society engages in discourses about Indonesian selves and Arab others through persons who do travel to the Middle East and through popular culture.

Therefore, this article brings cinematic representations and everyday representations of Indonesian selves and Arab others together. This exemplary selection provides a crosscut of the interplay of popular culture representations and everyday representations of social identities. In a combination of cultural analysis and anthropological field research, we aim at providing a complementary description of popular images of self and other that serve as reference points in the making of contemporary Indonesian Muslim identities. Moreover, the juxtaposition of on- and off-screen representations and of three groups of Indonesians who draw on first-hand experiences in the Middle East highlights the relevance of social class in contemporary Islamic lifestyles in Indonesia. Thus, the analysis relates to the interdependencies between spatial and social mobilities, gender, religion and images of self and other.

We unpack the argument by first discussing how ideas of Arabness in Indonesia relate to claims of religious authenticity. Secondly, we provide an overview of the fields and the films examined. Next, we analyze the gendered representations of Arab others and Indonesian selves and the contexts in which these representations occur. Finally, we present conclusions regarding what the complex negotiations of gendered representations indicate about social frictions and gender dynamics inherent in contemporary Muslim identity making in Indonesia.

The analysis draws on data from our research projects on cinematic representations of contemporary Indonesian masculinity (Eliyanah) and on images of the "Arab World" among labor migrants and Mecca pilgrims (Lücking) as well as our joint investigations. ${ }^{1}$

\section{Claims of Authenticity}

The negotiation of social identities among Indonesian Muslims must be considered against the backdrop of historical and contemporary debates on Islamic authenticity. Heterogeneity between and within Islamic communities continues to pose challenges to the establishment of a united Islamic community, the $u m m a h^{2}$. At times, this heterogeneity sparks acts of identification and differentiation among Muslims, through which claims to authenticity are hotly contested. In such contests, believers and academics question a common premise of authenticity: geographical proximity to the birthplace of the religion (Kahn 2015). In Indonesia, intensified Islamization deepens the contestation of authenticity, one of the most crucial dynamics of social change since the early 1990s. As an example, Woodward et al. (2012), observe that some religious leaders publicly make claims to religious authenticity by ridiculing other Muslims' practices. Among those other Muslims are Arab Muslims.

In this process of othering, various Arabic cultures are subsumed under the label "Arab", which refers to the region in the Middle East and also means "being Arabic" (Abaza 2007; Lücking 2016; Slama 2008, 2015). Clearly, "Arab" culture is not only homogenized and generalized in Western orientalist representations (Said 1978), but also in non-Arab Muslim regions. However, as some parts of "Arabness", such as the language of the Qur'an, are part and parcel of Islamic religious practice, the othering is only partial. "Arab" is a rather vague category that carries multiple connotations referring to language, ethnicity, culture, outward appearance, region and also ideological streams such as the radical or Wahhabi interpretations of Islam. In rendering attention to these emic generalizations of

1 We combined insights from our individual PhD projects in the framework of the Go8-DAAD Joint Research Cooperation Scheme.

2 Ummah refers to all people united by the Islamic faith. It encapsulates the global Islamic community. 
"Arab", this article examines the ways in which particular groups of Indonesian Muslims who have traveled to and/or lived in the Middle East define their authentic Muslim identities through processes of othering people and ideas that they label as "Arab".

The terrorist attack of $9 / 11$ and other acts of violence committed in the name of Islam intensified the tension among various groups of Muslims in Indonesia and globally. Muslims who abhor the violence claim that the perpetrators have failed to grasp the true teaching of Islam. This is exemplified in the view of the late Abdurrahman Wahid, the fourth president of Indonesia, who was also a notable Muslim leader in the country and globally. Wahid (Wahid 2005) not only claimed that acts of violence do not represent authentic Islam, but also pinpointed the ideology behind them:

"An extreme and perverse ideology in the minds of fanatics is what directly threatens us (specifically, Wahhabi/Salafi ideology-a minority fundamentalist religious cult fueled by petrodollars)" (p. 5) (brackets in original).

Underlying Wahid's statement is an implicit claim of his own superior understanding of Islam and what is considered "authentic" Islamic practice. Blaming Wahhabi/Salafi ideology as inspiring violence indirectly suggests a hierarchy between Indonesian Muslims and other Muslims, in this case the followers of Wahhabi/Salafi ideology, who are perceived as being predominantly Arab. In Indonesian public discourse, Wahhabism is usually associated with violence, religious bigotry and misogyny (Rohmaniyah and Woodward 2012, p. 2). In the global context, the involvement of Wahhabi Muslims from Saudi Arabia in the 9/11 terrorist attacks has resulted in a tendency to equate Arab Islamic traditions with violence. This tendency is termed the Arabization of Terrorism by Ronald Hall (Hall 2003). Different from Islamophobia in the Western world, many Indonesian Muslims perceive not religion (Islam) but ethnicity (Arabness) as the cause of violence. Therefore, localized manifestations of Islamophobia among Muslims in Indonesia can be described as “Arab-phobia" (Lücking 2017, p. 198).

In Indonesia, the phenomenon of the Arabization of terrorism materializes in renewed anxiety concerning Arab Muslims in the wake of Islamization and the power vacuum in post-New Order Indonesia. The ethnicization of terrorism is related to the argument that Saudi Arabia supports Wahhabism in Indonesia, and that leading figures in Indonesian Jihadist groups such as Ja'far Umar Thalib, Habib Rizieq Shihab and Abu Bakar Ba'ashir are of Arab descentAbaza (2007) and Slama (2008) highlight the growing racism against Hadhrami people (Indonesians of Arab descent) in relation to the accusation of radical tendencies. The high proportion of Arab descendants among the leadership positions in Islamic radial groups such as the Islamic Defenders Front (FPI) (Woodward et al. 2012), the growing religious intolerance seen as resulting from the spread of Wahhabi teachings (Wieringa 2006, p. 3; Rodemeier 2009, p. 54), the rising support for Sharia law in the wake of decentralization (Wieringa 2006; Bush 2008), and the increasing media reports of violence experienced by Indonesian migrant workers in the Arab World (Silvey 2012, p. 427; Chan 2014) have arguably fueled the contemporary anxiety about Arab Muslims in Indonesia.

Interestingly, this renewed anxiety about Arab Muslims occurs simultaneously with renewed interest in the Arab World and Arab Muslims. More and more Indonesian Muslims participate in various religious gatherings led by Hadhrami descendants (Slama 2008, 2015; Woodward et al. 2012) and there is growing interest in the exploration of Middle Eastern Muslim fashion in Indonesian fashion culture, such as abaya and the face veil (Nef Saluz 2007), for similar trends in Malaysia (Thimm 2015). Moreover, travel to the region for the hajj pilgrimage has increased, as seen in the long waiting list for first-time pilgrims (Directorate of Hajj and Umrah of Ministry of Religious Affairs of Republic of Indonesia 2015) and the exponential increase of umrah, the minor pilgrimage, that can be done at almost any time of the year, in contrast to the hajj, which falls on specific dates in the Islamic calendar (Harian Umum Pelita 2014). Since the 1980s, the Middle East has also been a major destination for Indonesian Muslim labor migrants (IRIN 2009; Silvey 2004, p. 250). Furthermore, Indonesian Muslims sustain interest in studying in Middle Eastern educational institutions, especially in Cairo and Mecca (Abaza 2007; Schlehe and Nisa 2016). This ambivalent relationship with the "Arab World" provokes the 
question: What role do the actual experiences of mobility towards the Middle East play in contestations over authenticity?

Our analysis of how Indonesian Muslims engage with ideas of authenticity in relation to Arab others departs from the understanding that authenticity is a matter of perspective. However, there are conflicts over different perspectives because the social actors do not understand them as individual opinion but as objective fact. Lambek (1993) demonstrates how people claim objectivity of knowledge by putting their ideas into practice, which creates social realities. He argues that "embodiment provides the ultimate ground for legitimating objective knowledge, rendering it experientially real and conforming its presence in and for the bearer or recipient" (Lambek 1993, p. 307). We consider mobility as an opportunity for such embodied experiences and shall analyze the interdependence of discursive and experiential dimensions in claims of authenticity. Here, we carefully consider the power relations in defining authenticity (cf. (Winarnita 2016)). Unraveling various components in defining authentic Muslim selves, such as religious, gender and class identities, serves to provide understanding of contemporary Muslim lifestyles in Indonesia.

The issue of Indonesian Islamic authenticity has captivated Indonesian Muslim intellectuals as well as Western social scientists since the 1960s. Well-known scientists such as Geertz (Geertz 1976), Jay (Jay 1969), and Anderson (Anderson 1972) allude to Indonesian Islam's nominal and/or syncretic characteristics, and deny its authenticity due to its distance from the center of Islamic civilizational force in the Middle East (Hefner and Horvatich 1999, p. 8). Although this argument has many times been refuted (i.e., by (Abaza 2007; Bowen 1993; Hefner and Horvatich 1999; Newland 2000)), the authenticity of Islam, as adhered to by Indonesians, continues to be a recurring theme regarding Indonesian Islam. Van Bruinessen (2013) shows that the religious move against Middle Eastern as well as Western-influenced Muslim scholars continues to center around claims of authenticity. We would like to contribute to this conversation by showing that claims of authenticity among Indonesian Muslims who have experienced direct contact with Arab Muslims is gendered, class segmented and substantially shaped by the socio-cultural values in the domestic context.

Instead of investigating the opinions of Indonesian Muslim scholars, we are interested in understanding the perspectives of the general public. Most of the pilgrims, labor migrants (mainly domestic workers), and students are ordinary people who seek to make sense of their encounters with Arab culture in their everyday life and personal biography rather than consciously nourishing a public discourse or engaging in a theological debate. Nevertheless, public debates do have an impact on their personal interpretations. With this interest in everyday practices and popular culture, we look at onand off-screen representations.

\section{The Fields and the Films}

We combine the perspectives of cultural studies and anthropology by focusing on Indonesians who have had direct contact with Arab culture and customs through different experiences of mobility. This joint project sprung from our respective $\mathrm{PhD}$ projects and was enabled through a cooperation between the Australian National University and the University of Freiburg, funded by the Go8-DAAD Joint Cooperation Scheme. Eliyanah undertook the cultural analysis of the texts and production of two contemporary Indonesian films: Ayat-Ayat Cinta (Bramantyo 2008) (The Verses of Love, hereafter abbreviated as AAC) and Ketika Cinta Bertasbih (Umam 2009a, 2009b) (When Love Glorifies God, hereafter abbreviated as $\mathrm{KCB})^{3}$. To do so, Eliyanah carried out a close reading of the films to understand how Indonesian Muslims, men and women, are depicted cinematically in relation to their Arab counterparts. In order to complement the close reading, Eliyanah also conducted a series of in-depth

3 This film is a duology: Ketika Cinta Bertasbih 1 and Ketika Cinta Bertasbih 2. Both were made by the same principal crew of filmmakers and were produced by the same film company. They were released in March and September 2009 respectively. Since they constitute a single plot, this article refers to them as a single entity with the name Ketika Cinta Bertasbih (KCB). 
interviews with nine principal filmmakers, comprising a director, scriptwriters, and producers involved in the films. Eliyanah also conducted interviews with two actors involved in the production of the films. As suggested by Hall (Hall 1997, p. 17), representations work as much as through "what is seen", in the context of this article the cinematic representations, and "the unseen". The interviews were the means to understand the latter aspect of representation, particularly in the context of how such cinematic representations of Indonesian Muslim selves and Arab others were possible to produce and were considered relevant by the creative minds behind the production at this particular moment in history.

We believe that commercial representations are not produced in a social vacuum. They are in part inspired by their contemporary social realities. The people involved in the production of the films are members of contemporary Indonesian society. Their filmmaking practice is a form of cultural practice intended to give meaning to events taking place around them at that moment in history. Intentionally or otherwise, they constitute a collective statement of what is considered "normal", and conversely, "not normal": the odd, the attractive, the scary, or the humorous within a certain regulated social setting (Heryanto 2014, p. 51). Indeed, the meanings offered by the filmmakers behind both films may not represent the heterogeneous Indonesian Muslims. The fact that both films were well received, as indicated by their stellar sales (Film Indonesia 2013), and also positive public testimonies from important figures, including then President Yudhoyono himself (Hasits 2008) and deputy leader of the Indonesian Muslim Cleric Council (MUI) (Wijoseno 2008), show that the films represent significant viewpoints shared by a great number of Indonesians at that time.

We selected the films firstly because both are based on novels written by an Al-Azhar graduate, were made by mostly Muslim filmmakers, and prominently feature experiences of Indonesians living and studying in the Middle East. We consider that the experience of Muslims behind the production of these films substantially informed how certain forms of "becoming Muslim" were represented cinematically. Secondly, they were produced and distributed in the period in which Islamization intensified in post-authoritarian and post-9/11 Indonesia (see previous section). Thirdly, AAC and $\mathrm{KCB}$ are milestones of Islamic-themed films in Indonesia. Films in this category tend to emphasize religiosity in their titles and content (Imanda 2012, pp. 92-93). The narratives are likely influenced by the novelists' experience of being in the Middle East, as reflected in the films' male protagonists (Sakai 2012, pp. 13-15). In fact, AAC and the first half of KCB are set in Cairo and the protagonists are mostly educated at Al-Azhar.

AAC revolves around Fahri, a postgraduate student at Al-Azhar University. The plot is driven primarily by his quest for an ideal wife. Fahri represents the "ideal" Muslim man: educated, pious, affectionate, and respectful of women. Fahri also represents a perfect match between Islam and modernity. As an "ideal" Muslim man, he is the love interest of many women, Muslim and non-Muslim. Fahri is a counter-representation of violent Muslim men, who in this film are mostly depicted as Arabs. However, despite being very resourceful in religious knowledge, he still needs to learn from more senior male Muslim scholars, mostly Arabs. He eventually marries a German-Turkish pious Muslim lady through a ta' $^{\prime}$ ruf ${ }^{4}$, arranged by his religious mentor.

KCB revolves around Azzam, a male Indonesian undergraduate student at Al-Azhar. Coming from a poor family, Azzam struggles to balance entrepreneurial work and study, which seems also to have been the experience of the writer (Sakai 2012, p. 14). Azzam is an "ideal" Muslim man, idolized by several Muslim women. Like Fahri in AAC, through ta'aruf Azzam marries Anna, the representation of an ideal Muslim woman: educated, independent, pious, affectionate, and pretty.

Lücking conducted fourteen months of anthropological fieldwork in Central Java and Madura in 2013 and 2014. A substantial part of the fieldwork was residence with labor migrants and pilgrims in

4 Islamic match-making process, in which a man (with his family) meets a woman through a religious teacher or family member and in the presence of the woman's family. 
two villages and two urban areas. Participation in everyday life enabled conversations that developed from natural daily interactions. More formalized interviews-a form of conversation alien to many research participants-were conducted to a lesser extent. With the research participants' consent, the data was documented in research logs and where possible recorded and transcribed. This written material has been coded in the methodological tradition of Grounded Theory (Corbin and Strauss 1990). In the article at hand, we present the findings through "ethnographic snapshots" of the experiences of five research participants: ${ }^{5}$ Dewi, a University student in urban Yogyakarta who participated in the hajj in 2012 as one of the youngest pilgrims; Ibu Anwar ${ }^{6}$, an elderly lady in rural Madura who accomplished the umrah in a group of fellow widowed women, Pak Mariadi ${ }^{7}$, a hajj returnee in rural Yogyakarta, Siti, a thirty-year old labor migrant who has been working in Kuwait and Abu Dhabi, and Ibu Anisa, who lives in the same village as Siti and worked in Saudi Arabia. Despite their different ages, genders and residence in urban and rural areas, all five persons can be considered members of the middle class when it comes to their living standards and their self-perceptions. However, many fellow Indonesians, especially urban middle class members who work in high skill sectors, do not consider migrant returnees such as Siti and Ibu Anisa as belonging to the same social class. This is evident in the terminology used to refer to one's own as well as others' social status. Siti and Ibu Anisa argued that others labeled them buruh migran (migrant workers). Indeed, their village had been introduced to me as kantong $T K W,{ }^{8}$ which literally means "female labor migrant pocket". The academics, civil servants and labor rights activists who told me about the village had used the term "kantong" metaphorically for "village". As something small, insignificant and compact, the term evokes the image of a secluded place with a high concentration of migrant workers. Siti and Ibu Anisa, who emphasized their material wealth and their savoir-vivre, complained about the stigma of being labeled as migrant workers. This highlights that the definition of who belongs to the middle class is subjective and contested. Interlocutors from urban environments who work in service delivery or white collar jobs argued that migrant women would have a consumptive lifestyle and would not invest their earnings sustainably.

Dewi, Ibu Anwar and Pak Mariadi are respected members of their communities. Dewi became the leader of a students' organization at her university. Ibu Anwar took over the role as head of the family after her husband died and is active in neighborhood meetings. Pak Mariadi held the position of neighborhood chief during the time of inquiry. This indicates that social status is not only related to materiality but also to prestige, education and social networks. Terms such as "middle class" and "migrant worker" are emic categories that mark social hierarchies. The pilgrimage significantly boosted the status of Dewi, Ibu Anwar and Pak Mariadi, while Siti and Ibu Anisa are labeled lower class migrant women, even though they accomplished the pilgrimage more than once during their stays abroad.

Thus, despite having the same destination, the experiences, especially the return experiences, of migrants and pilgrims differ remarkably. In the attempt to make the journey meaningful upon return, different images of the Arab World and of Arabness serve as guiding references in the identity constructions of labor migrants and pilgrims (Lücking 2014, 2016, 2017). These guiding references are rather heterogeneous, for instance the image of the Arab World as the Holy Land in advertisements for pilgrimage travel agencies or the Arab World as a harsh environment in reports about the ill treatment of labor migrants.

The common thread running through the ethnographic fieldwork and the films is travel to the Middle East, which has often been associated with increased piety and also with intensified

5 Pseudonyms are used to name the interlocutors, except the filmmakers. The interviews were conducted in Bahasa Indonesia. For the purpose of this article, the excerpts from the interview are presented in English translation. Lücking translated the fieldwork interviews with labor migrants and pilgrims, and Eliyanah translated those with the filmmakers.

6 "Ibu" literally means "mother" and is the common address for married women in Indonesia, comparable to Mrs.

7 "Pak," an abbreviation of "Bapak," literally means "father" and is the common Indonesian address for men, comparable to Mr. or Sir.

8 TKW is an abbreviation for Tenaga Kerja Wanita (female labor migrant). 
identification with Arab Islamic practices, which are sometimes considered more authentic than Indonesian Islamic practices (Berg 2011, p. 231). We do not intend to make a systematic comparison between everyday life and cinematic representations by putting the cultural analysis and ethnography side by side in this article. We rather deal with the complementary and interdependent notion of onand off-screen representations. Returnees from the Middle East often display their enlightenment by adopting Arabic language, clothing style and customs. However, on a discursive level, students, migrants and pilgrims question the authenticity of Arabness. In order to highlight the ambivalent and sometimes contradictory meanings of the term "Arab", we use inverted commas whenever we refer to the concept of Arabness in emic or ambivalent categories. In contrast to the emic use of the term "Arab", our etic category of "Arab others" refers to the results of our analysis of stereotypical representations of Arabness.

\section{Gendered Moralities and Religious Authenticity}

Our analysis reveals that gendered moral visions-ideas of what constitutes good Muslim men and women-feature prominently in the ways Indonesian Muslims in our investigation construct authentic Muslim selves in relation to their Arab others. There is no outright admiration of, or aversion to Arab others, but there certainly is constant questioning of their religious authenticity. The simultaneous admiration and aversion to Arabs' gendered moral visions signify the complex social relationship developed by Indonesian Muslims to their Arab counterparts. Arab Muslims on the one hand are models of authentic Islamic practice. Yet, on the other hand, they are also cast as un-Islamic. As Indonesian Muslims other Arab Muslims primarily by depicting the latter's gendered moral visions as contradictory to (Indonesian) Islamic values, they undermine the authenticity of the version of Islam performed by their Arab counterparts, and promote their own superior version of Islam as more authentic. Whereas Indonesians perceive that there are positive and negative stereotypes of Arab men and women, many Indonesians believe that the "true" (or pious) versions of men and women are prevalent in their own society. In other words, the concept of authenticity among Indonesian Muslims at this point in history is anchored at "home" despite their experience of contact with the region and people long believed to be central to Islamic culture. The established distinction between central and peripheral Islam can no longer be sustained, as the so-called periphery also claims to be as authentic, if not more authentic, as the center.

\subsection{Representations of Arab Muslim Men}

Our research participants and the protagonists of the films hold a complex view of Arab men. On the one hand, Arab men are cast as the ideals, whose morality is to be emulated by Indonesian Muslims. On the other hand, Arab men are viewed as immoral because they are perceived as expressing their manliness in harsh verbal expressions and violence, including violence against women and minority groups. This negative view of Arab men represents the perception of the other, as distinct from Indonesian Muslim men.

When pilgrims and labor migrants discuss spirituality and authentic Islam in Saudi Arabia, they mainly refer to public practices of Islamic norms and rituals by Arab men. In pilgrimage preparation courses, Dewi and Ibu Anwar had learned that Arab people are particularly pious:

"At the time of prayer, all shops will close and everyone heads immediately to the mosque for prayer. In Saudi Arabia people do pray on time, and will stop all other activities."

This image of the Arab world as a particularly pious society is represented on the cinema screen too. In both of the films we analyzed, the protagonists are students at Al-Azhar, the oldest Islamic education institution in the world and one of the primary destinations for Indonesian scholars in

9 Pilgrimage preparation course at Hasuna Tour Yogyakarta, 2 March 2013, translation by Lücking. 
their pursuit of Islamic knowledge since the 19th century (Laffan 2004, p. 2). Orienting the pursuit of knowledge of Islam towards the Arab world is a strong representation of the position of Indonesian Muslims as inferior to the Arab Muslims. Moreover, male Arab Muslim scholars, in particular, are depicted as role models and thinkers whose views and practices are to be emulated by Indonesian Muslims seeking to express their authentic Muslim selves. The male protagonists look up to their male lecturers and mentors, who are mostly Arabs. Fahri in AAC greatly respects Syech Usman, who serves as a model Muslim man for him. Fahri learns from him about the importance of marriage and man-woman relations in Islam. Moreover, in both films, the works of Middle Eastern male scholars, such as Ibnu Qudamah in $\mathrm{KCB}$, are often cited to justify certain gendered religious practices as authentically Islamic.

However, this does not mean that Indonesian men are represented as less knowledgeable, and thus less authentic, than Arab men. AAC, for example, depicts Indonesians as pious and educated Muslim men, as a resource of authentic Islamic knowledge. This is shown through a scene in which Fahri provides information to a female non-Muslim American journalist on the status and rights of women in Islam. An Indonesian Muslim man becoming a producer of knowledge about Islam in the land in which the oldest Islamic studies center is located is a strong statement of authenticity. Fahri's ability to convey knowledge of a more authentic version of Islam makes him an ideal Muslim man in the eyes of both non-Muslim and Muslim women. The film thus makes a strong statement that Indonesian Muslim men can be as authentic as their Arab mentors.

The positioning of an Indonesian Muslim as a representation of authentic Islam in this context deserves further critical exploration. An interview with the director of photography of AAC, Faozan Rizal, revealed that he and his Muslim filmmaking team considered that it was timely to produce a representation of Indonesian Islam as authentic as, or even more authentic than, the Arab version. According to Rizal:

"We are concerned because after reformasi, we tend to be Arabized. We are the country with the largest Muslim population in the world, why do we have to emulate the Arabs? It is they who have to emulate us." 10

The term "Arab" in the interview quote refers to a bifurcated meaning. Firstly, it refers to people of Hadhrami descent in Indonesia who hold increasingly significant public roles in the public expression of religious piety in the post-authoritarian period, or in Rizal's term reformasi. In the previous section, we explained about the increasing anxiety about Hadhrami-led radical Islamists, in contrast with the more culturally based Hadhrami Islamists in Indonesia. The concern about violent Arabs within Indonesia inspired the production of Indonesian exemplars of Muslim men, such as Fahri in AAC, whose Muslim masculinity is in fact more desirable.

Secondly, taking into account the fact that the novel and film were produced in the aftermath of 9/11, the "Arab" in the above quote also represents the Arabization of terrorism. Through Fahri's exemplary Muslim character, the film distances Indonesian Muslims from the violence committed in the name of religion by "Arab" Muslims.

Representations of Arab men being violent contrast with the image of their piety. This ambivalence is also prevalent in migrants' and pilgrims' narratives. While on the one hand travel guides explain that Arabs are particularly pious, as in the statement above, on the other hand, they warn pilgrims of their harshness. Dewi recounted:

“They like to shout. They enjoy being harsh. In Indonesia we don't do that. We keep our anger inside. They pointed at me, when accidentally my skirt was lifted a bit, shouting "haram, haram," but it was not on purpose. They are so rude."11

10 Personal communication with Faozan Rizal, 22 May 2014.

11 Personal communication with Dewi, 25 January 2013. 
Ibu Anwar explained that she had heard about harassment of women and the pilgrimage guide had advised her to remain in a group at all times. Moreover, she argued that Arabs and also Africans had no sense of hygiene or politeness. "They don't know how to behave and they are wild,"12 she claimed. The racial stereotypes of tall, big and coarse Arab and African men are also visually depicted in pilgrimage comic guidebooks (Luqman 2000, p. 100).

Furthermore, Indonesian pilgrimage returnees portrayed Arab Muslim men as self-centered. Dewi illustrated this by describing how Arab men would selfishly make their way through the crowds during pilgrimage rituals and mock pilgrimage groups from other countries. Dewi recounted how an Arab man had asked her if she would like to become his second wife. "They consider Asian women as maids and prostitutes," she said in outrage, and continued: "polygamy is not acceptable and fortunately not very common in Indonesia, he was crazy." 13 Moreover, she depicted Arab men as verbally kasar (harsh), speaking loudly, acting in a sombong (arrogant) way, looking down on Asians and Africans. Pak Mariadi described Arabs' prejudice against Indonesians in the following way.

"( . . ) The person who does the call to prayer in our local mosque here is a graduate from Universitas Gadjah Mada (UGM) with the best grades. He got cum laude in almost everything. Then he went to Saudi Arabia for two years and became a driver. Even though he is a technical engineer, he became a driver there. I asked him why he did not get a work permit as an architect. Why? Because the Arabs said: 'Sorry brother, the work permits for architects and technical engineers are only given to Arabs, French people or Russians,' that's what they said, no work permits for Indonesians."14

A feeling of solidarity with fellow Indonesians who work in the Gulf nourishes criticism of alleged Arab superiority. This is especially relevant with regard to the treatment of women. Many pilgrims claimed that Arab men were potentially violent and treat women badly. Therefore, male pilgrims positioned themselves as protectors of female pilgrims. Ibu Anwar, who accomplished the umrah in a group of widowed women, also considered the Indonesian nation state and the travel agencies, who guide pilgrims' journeys, as protectors in this matter.

The most widespread image of female victims of Arab harshness are, however, female migrant workers (Brenner 1999, Chan 2014, 2015). From their own observations within the intimacy of family life, female labor migrants recounted that Arab men treated their wives badly, were likely to be polygamous and sexually attracted to Indonesian domestic assistants. Siti, who had worked in Kuwait and Abu Dhabi, concluded that the Arabs were really "harsh" and it required bravery to go there. She described herself as "pemberani", which means the brave one, and further explained that she considers it important not to allow the Arabs to "step on Indonesians" (in Indonesian "menginjak"), which is a phrase frequently used to refer to behavior that is discriminatory against Indonesians. Obviously, our research participants doubted the alleged piety of Arab men and also emphasized their own dignity. Pak Mariadi, for instance, concluded:

"But really, the Arab people are just crazy, aren't they? The Arabs are harsh. It's not me saying that the Arabs are crazy; it's the holy book. The holy book says that al-Arabīyūn, the Arabs, are people that really like to argue and are hypocrites. It's the holy book that states that. That's why all the prophets were sent there, because they need that there. Here we do not need a prophet, you know. Because we are just good."15

In expressing his doubts about the authenticity of Arab piety, Pak Mariadi refers to a higher authority, namely "the holy book". This legitimization of views often occurs through a distinction

12 Personal communication with Ibu Anwar, 3 July 2014

13 Personal communication with Dewi, 25 January 2013.

14 Personal communication with Pak Mariadi, 1 March 2013.

15 Personal communication with Pak Mariadi, 1 March 2013. 
between culture and religion. Migrants and pilgrims acknowledge male Arab Muslims' religiosity but they criticize their cultural habits, judging them to be un-Islamic. They conclude that Arabs would probably fulfill the five pillars of Islam but they would not represent ideal moral Muslim men, in contrast to caring, polite and responsible Indonesian men.

This idea of a need for protection against Arabs corresponds with the narrative of both films, which challenge the contemporary popular media images of Islam and propaganda campaigns related to the war against terrorism in the aftermath of $9 / 11$. In international mass media, Islam is often depicted as a religion which discriminates against women and which gives license to Muslim men to commit violence against and subjugate women (Haddad 2007). AAC and KCB contradict this discourse through their Indonesian male protagonists. The male protagonists are counter-representations of the violent and harsh Muslim men, cinematically represented mostly as Arabs. Male Indonesian Muslim scholars on screen reinterpret and reinforce their own sense of Muslim identity, as they engage with male and female Arab others.

In both films, Arab men constitute all the primary antagonists to be morally corrected by the Indonesian Muslim male protagonists. These Arab men are portrayed as physically, verbally, and sexually abusive to women, intolerant to difference, manipulative, criminal, and often violent. These negative stereotypes co-exist with the positive ones discussed above.

AAC is remarkable in representing Indonesian Muslim men as the image of "authentic" Muslimhood and Arab Islam as less authentic. A scene of a scuffle on a train involving a pious Arab man and Fahri clearly suggests the superior social status of pious Indonesian Muslim men in relation to violent Arab others. In the scene, Fahri corrects what is portrayed as the "un-Islamic" behavior of Arab men in the treatment of (female) foreigners and a Muslim woman by bringing up a hadith-based justification. This scene represents Fahri's doubt about the authenticity of the Arab man's Islamic view. Just as in the statement by Pak Mariadi, "the holy book", the Qur'an, is used to legitimize the criticism of Arab behavior. It is again clear that gender is central in defining the authenticity of Indonesian Muslims and the othering of Arab Muslims. Whereas Indonesian men stand up for women's rights, Arab men are the opposite, and are in fact seen as the cause of the problem of women's rights violations. To be a morally authentic Muslim man, as suggested by the films and the pilgrims' narratives, one has to be able to protect and speak up for Muslim women.

This is where the complexity lies, where the state of contradiction is encountered by Indonesian Muslims, on- and off-screen, when they travel to the Middle East and negotiate their Muslim social identity in relation to the Arab others. They learn from and greatly respect pious male Muslim models, but they criticize what they perceive and represent as narrow-minded and potentially abusive Arab men, whom they seek to correct through their own morally superior behavior.

\subsection{Representations of Arab Muslim Women}

Like the ambiguous representations of Arab Muslim men, Arab Muslim women are also portrayed in a contradictory manner. In fact, encounters with Arab Muslim women appear to be even more nuanced. Each sub-group has quite different experiences of encounters with female Arab Muslim others.

Generally, pilgrims and labor migrants mentioned gender segregation as one of the biggest differences between Indonesia and Saudi Arabia and other countries in the Gulf. As an example, the pilgrimage returnees Dewi and Ibu Anwar, like many others, recounted that encounters with Arab people during pilgrimage are in fact restricted to men, as women are "hidden" behind veils and in the private sphere (cf. (Sidani 2005, p. 500)). Labor migrants who happened to work in the private sphere had much to say about Arab women as their employers. Instead of empathizing with these women, migrant women's evaluation of their female Arab employers is highly critical. In fact, perceptions of Arab women as passive victims of patriarchal and violent structures are extended into an overall critical view of female Arabs. Against the backdrop of employer-employee power relationships, migrant domestic workers described their female Arab employers as immoral, lazy, pampered, full of suspicion 
and jealousy, and as ungenerous. Siti argued that beneath the full body veil, Arab women would wear expensive jewelry and sexy clothes. In women-only environments, they would talk and behave "dirty". The expensive clothing and immoral mindset totally contradicted the Islamic ideal of modesty and chastity. Siti, like other migrant women, denounced Arab female dress codes as hypocritical, and not related to sincere piety (cf. (Sidani 2005, Le Renard 2008)). In line with questioning the authenticity of dressing habits, Siti and Ibu Anisa pointed out that Arab women would rarely perform the daily prayers and if they did, they would only be allowed to do so at home, in contrast to Indonesian Muslim women who are used to performing prayers at mosques just as Indonesian Muslim men do. In general, Siti and Ibu Anisa praised Asian culture as more woman-friendly and thus superior. Other popular criticisms mentioned by the migrant workers were hygiene, lifestyle, and a general lack of modesty and shame. Ibu Anisa illustrated this by saying:

"There, they [the Arab women] do not take care of themselves; the women there, they just sleep and eat, so their physical appearance isn't good. They never work, so they become loose and slack. They never do sports. They are just at home. Men do the shopping and everything, the daily needs. There is nothing that the women do. Just sleep and bear children." 16

The othering of Arab Muslim women in post-migration narratives goes hand in hand with an idealization of images of Javanese moral femininity, involving softness, refinement, restraint, humility, and politeness (Mulder 1997; Winarnita 2016, p. 24). Moreover, migrant women emphasized greater freedom in exercising their female agency in their hometowns in Java without fear of reprimand from their husbands or a strict patriarchal system. These qualities and opportunities in Java were seen as more fitting representations of Islam than those attitudes displayed by Arab Muslim women and Arab culture, supposedly representing "authentic" Islam.

In the films, Indonesian students interact with Arab Muslim women both in their homes and in the public sphere, such as in educational institutions. To this group of Indonesian Muslims, some Arab Muslim women, such as the female lecturers and wives of the male lecturers, are models of feminine piety and morality. There is no questioning their authentic Muslimhood, and Indonesian women are encouraged to emulate these women's examples of feminine Muslimhood. In the films, female Indonesian students at Al-Azhar see their female lecturers and the wives of their mentors as feminine role models. They admire these Arab Muslim women. Anna, the female protagonist of KCB, for instance, greatly respects her female lecturers at Al-Azhar's campus for female students. Anna admires the depth of her lecturer's knowledge and femininity. In AAC, Aisyah, the female protagonist, is half Middle Eastern and she becomes the most ideal candidate to be Fahri's wife. Aisyah represents an ideal Muslim woman in the film. She is pretty, intelligent, independent, pious, supportive of her husband, and dresses modestly.

However, few other women are cinematically depicted as victims of the patriarchy and/or perpetrators of crime and violence. Most female antagonists in the films are Arab women who are to be corrected by the ideal Indonesian Muslim men. In KCB, an Arab woman represents the commonly perceived Arab moral decadence: she makes sexual advancements on an Indonesian Muslim male student, and then blackmails him by falsely accusing him of adultery. In AAC, Arab Muslim women are also portrayed as victims of the patriarchal Muslim Arab men. One female Arab Muslim is a victim of domestic violence and her frustration leads her to be a manipulative character. Against these Arab Muslims, Indonesian Muslim men and women are counter-representations who can provide corrections and lead them to a perceived "better" version of Islam.

The representation of Arab women as victims of gender-based violence and discrimination apparently resonates with the stereotypical view of the Arab world. Over the years, the Indonesian

16 Personal communication with Ibu Anisa, 21 March 2014. 
media have covered myriad stories on the restrictions imposed on women in the gulf countries. A hashtag search on Indonesian media with Islamic backgrounds such as Republika Online, for instance, produces more articles on the restrictions imposed on women in Saudi Arabia than on their rights. The media have also been inundated by stories of abuses experienced by Indonesian female domestic workers working in the region (Hugo 2003). Therefore, according to the novelist, who was also involved in the film production of $\mathrm{KCB}$, the film version of $\mathrm{KCB}$ was intended to provide visualization of the respected status and position of women in Islam:

"In the film Ketika Cinta Bertasbih, women are represented as holding high status in Islam and are liberated. They have the liberty to choose whom to marry and set conditions to be fulfilled by their future husbands in order for the marriage to take place, as long as the conditions guarantee the wellbeing of the women, her families and their future husbands." (Habiburrahman El Shirazy in an interview with (Nuh 2008)).

Taking into account the stereotypical treatment of women in the Arab world, the statement given by the novelist strengthens the assertion that the version of Islam represented through Indonesian Muslim characters in $\mathrm{KCB}$, as well as in $\mathrm{AAC}$, is premised more strongly on the authentic version of Islam which respects women, affords them agency and is non-discriminatory.

However, despite reservations regarding the lifestyles of Arab women, Indonesian Muslim women mark their identity as pious followers by adopting and creatively modifying Arabic fashion styles. We will discuss this in more detail in the following section.

\subsection{Arab Style}

The experience of mobility manifests in the embodiment of style, which is gendered and divided by class. In this case, we will show a slightly different experience of the embodiment of mobility among the three groups of travelling Indonesians. While veiling is prevalent as a marker of feminine piety among pilgrims and students, it is denounced as a less significant Islamic teaching and a symbol of hypocrisy by female labor migrants. As for male students represented in the films, unlike the male pilgrim returnees they do not adopt distinct clothing styles to mark their increased piety.

Despite discursive critique of Arab culture and customs, many Indonesian pilgrims, both male and female, mark their status as pilgrimage returnees through distinct clothing, which is often labeled as an Arab style. For outside observers, it causes some confusion that the exact same term, namely "Arab", is used in different emic categorizations: in reference to ideology, culture and fashion. The last of these has much more positive connotations than the first two categories.

Among male pilgrimage returnees, white, ankle-long garments called jubbah are popular at special occasions, and among women the long abaya robes are in vogue. Especially in orthodox regions such as Madura, Arab accessories, such as the checked kufiyah cloth, are popular for marking one's status as a hajj returnee. Likewise, other fashion styles, which originate in Indonesia's lively Muslim fashion industry, are labeled as Arab-inspired, and have become synonymous with piety among consumers. Dewi, Ibu Anwar and Pak Mariadi brought home Arab souvenirs from their journeys, including Arab clothing, which they would wear as a sign of their completion of the pilgrimage.

However, a slightly different experience of embodiment of Arab style is depicted by the male protagonists in AAC and KCB. The screen representations of ideal Muslim men are more heterogeneous. No Indonesian male Muslim graduate of Al-Azhar in the films is depicted as wearing typical traditional Middle Eastern long dress, such as the jubbah, and nor do they wear the Indonesian sarong. They mostly wear pants and shirts, including when performing religious rituals such as praying. Unlike the women, their clothing is not portrayed as symbolic of who is most Islamic.

To further explore notions of piety and fashion, Indonesian Muslim women arguably face greater pressure to express their religious authenticity through fashion than Indonesian Muslim men (cf. (Jones 2010)). In reference to Thimm (2015) who shows for Malaysian Muslims that the Arabic abaya can be a symbol of modernity as well as piety and in fact carries different meanings for different 
actors, we confirm that the alleged authenticity of dress is particularly controversial. Exploring "Arabic" fashion culture, such as wearing abaya and large veils, can become an embodied experience to express religious authenticity as well as modernity and-given the pressure to consume-social class. Off-screen, female pilgrims face more pressure to change their style upon return from pilgrimage, while male pilgrims do not face equal pressure. On-screen, the representations of ideal Muslim women, Arab and Indonesian, are homogenously veiled. The unveiled women are either non-Muslims or less ideal Muslim women. Fahri's second wife, upon her conversion, adopts veiling to affirm her authentic feminine Muslimhood (Paramaditha 2010). According to Eliyanah (2016), the increasing significance of veiling in symbolizing feminine piety in Indonesian cinema is a recent phenomenon, which started in the 1990s and has become an almost mandatory visual code in the twenty-first century. Although the veiling fashion adopted by female Muslim characters in Indonesian cinema varies, it is hard not to notice the increasing prevalence of abaya and large veils as symbols of superior feminine piety (Eliyanah 2016).

However, the expression of feminine morality and piety through the adoption of modest and decent dress, which is often reduced to straight cut abayas and large veils, albeit of various colors, is strongly questioned by most of the labor migrants taking part in this research. As these migrant workers assessed their female employers' modes of fashion in relation to morality and piety, they tended to denigrate the abayas, large veils, especially the face veils worn by their female employers as expressions of being munafik (hypocritical) and as mandatory clothing that is imposed upon women. While not denying that such fashion is Islamic, they tended to see the expression of piety in fashion as superficial.

The labor migrants carefully separated culture from religion, attributing negative stereotypes to Middle Eastern culture and not to Islam. Consequently, Siti, Ibu Anisa and other migrant women were not generally in favor of fashionable veiling practices. They would wear veils rather sporadically when traveling or attending official meetings, unlike the female pilgrims, such as Dewi and Ibu Anwar, and the female students on screen who wore them whenever they were in public and invested time and money in headscarf fashion. What labor migrants, pilgrims and students have in common is a distinction between culture (Arabness) and religion (Islam). Culture, rather than religious practice, is seen as problematic. However, the estimation of where to draw the boundaries between culture and religion obviously differs and therefore contradictory types of "Arabness" emerge: "Arabness" is a synonym for fundamentalism and harsh Middle Eastern culture as well as a symbol for superior Muslim morality and modernity. In emic conceptions and everyday language, these types are often not differentiated terminologically. What "Arab" means depends on the context.

\subsection{Images of Femininity and Claims of Authenticity}

In the representations of gendered moralities, the role of women is particularly central. Moral or immoral behavior and religious authenticity are mostly exemplified in representations of femininity and men's ability to preserve the "honor of women". Competing discourses battle over claims of authenticity, marking frictions in the broader socio-political context at the national and global levels. Strikingly, these claims of authenticity are male-dominated discourses both on- and off-screen, while moral femininity becomes the object of the discourses. Yet women are not merely passive participants; they actively negotiate the discourses at the level of practice.

Compared to other nations, Indonesia has a high percentage of female participation (approx. 50\%) in the hajj (Bianchi 2004, p. 69). Robert Bianchi relates Indonesian women's presence in commerce, land owning and their position in customary law in rural areas to the high level of female participation in the pilgrimage (Bianchi 2015, p. 74). However, in the ethnographic fieldwork from which we drew our data, it is evident that the decision makers in the context of the pilgrimage, such as civil servants in the Ministry of Religious Affairs and pilgrimage guides, are mainly male. As they are not only in charge of technical questions but also spiritual and cultural ones, these men obviously have remarkable influence in shaping leading discourses concerning Arab others and Indonesian selves. 
Indonesian labor migration to the Gulf is a female domain and many women are involved in the preparation and administration of labor migration, though the key decision makers appear to be men. Public discourse about the role of migrant women is linked to judgmental views of modesty in behavior and clothing style. These discourses revolve around migrant women's potential (im)morality as an indication of their economic success (Chan 2014, 2015; Silvey 2006; Winarnita 2016, p. 77).

Film production in Indonesia is also male-dominated, with the majority of films being directed by male filmmakers. Between 1998 and 2010, women filmmakers comprised only 13\% of the total 184 directors working in mainstream cinema (Kurnia 2014, p. 8). The films examined in this article were both adapted from novels written by a male graduate of Al-Azhar, and were directed and written by male Muslim filmmakers. Women occupied only minimal roles in the production, either as co-scriptwriters or co-producers. These roles provide the women with limited power to shape the story and characters. In fact, the female co-producer of KCB was not involved in story development at all, as suggested by the KCB scriptwriter Tantowi in an interview with Eliyanah ${ }^{17}$. In other words, the production is very much male-dominated.

Furthermore, in both films the prime protagonists are male. They are representations of ideal male Muslim masculinity and religious authenticity. They are both knowledgeable in terms of religion. Other people, Muslims and non-Muslims, men and women, often consult them about Islam. Fahri in AAC, for example, becomes the representation of Muslims, if not Islam, in terms of treatment of women in Islam. Not only does he set an example, but he can also explain the status of women in Islam. In short, knowledge about Arab others is mostly constructed by men although it often revolves around women and men-women relationships. This implies the underlying perception of hierarchy not only between Arab and Indonesian Muslim men but also between Muslim men and Muslim women more generally.

The migrants' and pilgrims' recollections of their experiences of mobility and the cinematic depictions of students' experiences in Egypt mirror how personal identity making is related to the general global and national controversies about religious authenticity, in which the role of women is equally central. At the national level, the distinction between Arab others and Indonesian Muslim selves is often expressed through statements about the status and treatment of women, as for instance in a statement by the Indonesian minister of religious affairs:

“For example, in many Middle Eastern countries, women have less freedom. They can't drive; they can't go anywhere on their own, they are not even admitted in religious sites. In Indonesia, they have more freedom." (Majalah Tempo 2015)

The minister of religious affairs is a prominent figure in the relationship between Indonesia and Saudi Arabia. The quote comes from an interview with a major print magazine on the state's support of a certain form of Islam that claimed to be more compassionate and accommodating of differences. This version of Islam is called Islam Nusantara, which means the Islam of the Indonesian archipelago. Thus, in this statement it is implied that Indonesian Muslim selves are socially constructed as superior to Arab others because the latter tend to treat women a discriminatory manner, i.e., women cannot drive or enter certain religious sites, unlike in Indonesia where women have more liberty.

In the domestic politics of Indonesia, especially in the post-authoritarian era, gendered conceptions of morality have become an important arena for the articulation of social identities in the intensified Islamization of contemporary Indonesia. As argued by Brenner (1999), control over public (gendered) moralities can lead to the acquisition of political power. Intertwined with claims of religious authenticity, these gendered moralities function as symbolic capital in the religious and political spheres (Winarnita 2016, pp. 33, 90). As an example, political power gambling has occurred through the implementation of partial Sharia law in several regions in Indonesia since the decentralization law

17 Personal communication with Imam Tantowi, 14 April 2014. 
was passed in 2001. Many sharia regulations contain recommendations for women's dress. In this undertaking, religious symbolism and the promotion of a certain image of femininity becomes a capital that various political actors - religious as well as secular parties — try to exploit.

However, even though it seems to be mainly men who compete in the discourses about Arab others and the morally superior Indonesian self, women are active at a practical level in their consumption and dress practices. In the transnational context of migration, pilgrimage and education abroad, mobile actors may relate to more than one dominant discourse. This is especially relevant in the context of migration. Winarnita (2016) argues that migrant women subvert dominant discourses in a playful manner. In her case study on migrant women dancers in Australia this took place through the exaggeration of stereotypes, which "was done for the pleasure and hilarity of being able to shock, as well as for the sense of power and popularity that accompanied it" (Winarnita 2016, p. 90). In the area of Islamic lifestyle consumption, women are joining in to define, reproduce, affirm, or contradict the discourses produced by men. This means that women are not the passive objects of male-dominated discourses but agents in the quest for authenticity and identity construction. As representations and practices are interrelated, we have to consider that women are not merely acting upon the male-dominated discourses but also challenge them. This is most obvious, for example, in the case of female labor migrants who do not adopt Arab-Islamic fashion culture to appear pious. This indicates that the "new" Indonesian Muslim identity is not only related to gender ideals but also to class. Who belongs to a certain class is a matter of negotiation. Female labor migrants cannot so easily access the social capital that Arabness entails, they do not promote Arabness and the ideas related to it in a similar way to female pilgrims, but challenge the discourse of a modern, economically successful, and fashionable Muslim along with its gender ideals.

\section{Conclusions}

Coming back to the question of how Indonesian Muslims engage with ideas of authenticity in relation to their Arab others, our analysis shows that gendered moralities are a significant demarcation of social identities and religious authenticity. They are markers of distinction between us and them. As the Indonesian Muslims we came across in our research strongly anchor the conceptions of gendered moralities to the idea of domestic culture, they transform the conceptions of gendered moralities into markers of superior authenticity in Islamic practice. Through their conceptions of superior Indonesian Islamic lifestyles, the subjects of our analysis socially depict Indonesia as central to contemporary Islamic cultures and knowledge. In this context, the boundary between center and periphery, which has been pivotal in the discussion of Islamic authenticity, crumbles.

The experiences of mobility substantially inform the justification for boundary making. Mobility provides an opportunity to engage with contemporary national and global issues, including Islamic authenticity. This engagement is discursive as well as practical. Through experiences of mobility, new opportunities for enactment and discussion open up. "Arabness" is embodied as much as it is narrated. Strikingly, adaptations of and demarcations from what is labeled as "Arab" in emic categories go beyond Arabness in the Middle East and are also directed at competitors within Indonesia. Identity making in the context of migrants', pilgrims' and students' experiences is consequently not only inspired by actual encounters with Arab others but also by international and national discourses. Representations of "Arabness" are embedded in these discourses and reveal social undercurrents in the construction of Muslim identities in contemporary Indonesia. There is a tendency to adopt an ambivalent view in constructing Arab others, and in reinforcing one's own notions of identity. In the context of our research, Indonesians represent Arab others both as models of authenticity and as people whose culture undermines important aspects of Islam, such as respect for women and humility. This means that the practice of othering in this context is partial and selective. There is an effort to become the "better Muslims", especially with regards to gender ideals. This partial othering comes along with a narrative of "taking the good" from outside influence and "leaving the bad elements" aside. In combination with Javanese culture this results in morally good Muslim individuals. 
Through the representations of Arab others, Indonesians position themselves as morally superior and as practicing more authentic Islam, thereby challenging the concept of geographical proximity to Mecca as the defining point in determining "authentic" Islam. At the core of Indonesians' ability to both accept and reject aspects of Arabness is the distinction between Arab cultural and religious practices. This distinction runs through narratives surrounding Arabness, and allows Indonesians to critically determine what they consider "authentic" Islam, rather than adopting all aspects in a wholesale manner. Thus, while the embodied mobile experiences appear to contribute to a differentiation between culture and religion, the question of what is perceived as culture and what is perceived as religion-in emic categories-remains controversial. It is this aspect that indicates social tensions in the negotiation of authentic Islamic lifestyles.

This is especially evident concerning women and womanhood as central to the respective discourses. Indonesian Muslims tend to use gendered moral visions to ground their claims to authenticity. The agents involved in the production of these moral visions are, for the most part, dominated by males. Gendered moral visions are shaped by staging an image of "modern Indonesian Muslim men and women" who claim to be the role models for "other" Muslims in Indonesia and the Middle East, if not globally. This version is promoted in films and among the urban middle class. Yet the case of the female labor migrants challenges these images of authentic and superior Islamic lifestyles. Their denunciation of hypocritical Islamic style hints at the conflictive notions of contemporary Muslim identity making. Obviously, spatial and social mobility do not go hand in hand. The physical embodied mobile experience becomes a source of legitimization in the endeavor to exploit various forms of capital from normative representations. However, in order to experience upward social mobility, the representations of Arab others have to fit in the home context.

The analysis of on- and off-screen representations of Arab others and Indonesian selves indicates that Indonesians critically engage with the globalized discourse of the Arabization of terrorism. By associating Arab culture with radical interpretations of Islam, Indonesian Muslims locate the problem of violence committed in the name of religion outside Indonesian society, although such acts of violence are also committed within Indonesia.

The distancing from religious radicalization and violence leads to the stylization of an image of harmonious, modern Indonesian Islam. Here, the films' narratives provide imagined solutions. The middle class pilgrims obviously engage with these imagined solutions. However, the stylization of a modern Indonesian Islam goes along with a claim of superiority that does not only concern the religious sphere.

We revealed that the "Arab style" of urban middle-class Muslims is not only a statement about piety but also about being rich and being removed from the working class (cf. (Jones 2010)). This is obvious in people's self-ascriptions as middle class and the stigmatization of working migrants. Clearly, there is another other in this context, namely the lower class, the poor and rural population from which the urban, formally educated middle-class Muslims distance themselves. Thus, the story about Indonesians' engagement with Arab others is also a story about othering and dealignment within their own society. Here, the adoption of Arab-Islamic style is a criterion of distinction for the middle class. The case of the labor migrants challenges the imagined solutions and dreams of a modern Islam and reveals how contested Muslim identities in Indonesia are at the nexus of the frictions and conflicts concerning the right interpretation of Islam, class affiliation, and gender roles.

We conclude that othering Arabness goes beyond encounters with Middle Eastern Arabs. The representations of the journey or residence abroad and of something potentially "foreign" are also a way to discuss issues related to inner-Indonesian tensions without directly pointing at them.

The analyses of on- and off-screen representations of travel experiences have shown that they are not dichotomous but rather are interrelated. Just like stories on the screen and stories in real life, mobile experiences are not detached from the home context. The juxtaposition of on- and off-screen representations and different mobile groups reveals fissures between different versions of "authentic" Muslim religiosity. Considering the competing claims of authenticity and the seemingly decentered 
position of the Arab World within the Muslim World, as shown in the example of Indonesians' relationships with Arab culture at the alleged center of the Muslim World, the idea of a global Muslim ummah continues to be contested. We agree with Hassan (Hassan 2006), that the future of the Muslim ummah will most likely be a wide range of differentiated regionalized ummahs, embodying the specific regions' unique characteristics of Islam, which have been socially and culturally molded and are nationally and internationally contested.

Acknowledgments: This joint publication is the result of the collaborative research exchange "Social Identities in Contemporary Indonesia: A New Framework of Studying Asia", led by Prof. Ariel Heryanto (The Australian National University) and Prof. Judith Schlehe (University of Freiburg) and funded by Go8-DAAD Joint Research Cooperation Scheme. We appreciate the feedback provided by Prof. Heryanto, Prof. Schlehe, and other project members: Meg Downes, Paritosha Kobbe, Maria Myutel, and Evamaria Sandkühler. Furthermore, we thank Alec Crutchley and Jennifer Plaistowe for their competent proofreading.

Author Contributions: Both authors equally contributed to the article at hand, from data collection, research design and analysis to preparing the manuscript for publication. The data stems from our individual $\mathrm{PhD}$ projects. Eliyanah collected data through close readings of the films and interviews with principal filmmakers and actors. She also carried out the cultural analysis on the films and their production politics. Lücking undertook anthropological research among labor migrants and Mecca pilgrims in rural and urban areas in Central Java and Madura. Throughout 2014 and 2015, we identified overlapping research interests and developed joint questions and arguments during meetings in Indonesia, Germany and Australia. Previous versions of the article were presented at conferences and workshops at the Australian National University and the University of Freiburg.

Conflicts of Interest: The authors declare no conflict of interest.

\section{References}

Abaza, Mona. 2007. More on the Shifting Worlds of Islam. The Middle East and Southeast Asia: A Troubled Relationship? The Muslim World 97: 419-36. [CrossRef]

Anderson, Benedict. 1972. The Idea of Power in Javanese Culture. In Culture and Politics in Indonesia. Edited by Claire Holt. Ithaca: Cornell University Press, pp. 1-69.

Berg, Birgit. 2011. "Authentic" Islamic Sound? Orkes Gambus Music, the Arab Idiom, and Sonic Symbols in Indonesian Islamic Musical Arts. In Divine Inspirations: Music and Islam in Indonesia. Edited by David D. Harnish and Anne K. Rasmussen. New York: Oxford University Press, pp. 207-40.

Bianchi, Robert. 2004. Guests of God: Pilgrimage and Politics in the Islamic World. New York: Oxford University Press.

Bianchi, Robert. 2015. The Hajj and Politics in Contemporary Turkey and Indonesia. In Hajj: Global Interactions through Pilgrimage. Edited by Luitgard E. M. Mols and Marjo Buitelaar. Leiden: Sidestone Press, pp. 65-84.

Bowen, John R. 1993. Muslims through Discourse: Religion and Ritual in Gayo Society. Princeton: Princeton University Press.

Brenner, Suzanne. 1999. On the Public Intimacy of the New Order: Images of Women in the Popular Indonesian Print Media. Indonesia 67: 13-38. [CrossRef]

Bush, Robin. 2008. Regional 'Sharia' Regulations in Indonesia: Anomaly or Symptom? In Expressing Islam: Religious Life and Politics in Indonesia. Edited by Greg Fealy and Sally White. Indonesia Update Series; Singapore: Institute of Southeast Asian Studies, pp. 174-91.

Chan, Carol. 2014. Gendered Morality and Development Narratives: The Case of Female Labor Migration from Indonesia. Sustainability 6: 6949-72. [CrossRef]

Chan, Carol. 2015. In Sickness and in Wealth. Inside Indonesia. Available online: http:/ / www.insideindonesia. org/in-sickness-and-in-wealth (accessed on 2 August 2015).

Corbin, Juliet M., and Anselm L. Strauss. 1990. Basics of Qualitative Research: Techniques and Procedures for Developing Grounded Theory. Los Angeles: Sage.

Directorate of Hajj and Umrah of Ministry of Religious Affairs of Republic of Indonesia. 2015. Hajj Waiting List. Available online: http:/ / haji.kemenag.go.id/v2/basisdata/waiting-list (accessed on 15 September 2015).

Eliyanah, Evi. 2016. Cinema: Representations on Commercial Films. In Encyclopedia of Women and Islamic Cultures: Supplement XIV. Edited by Suad Joseph. Available online: http://referenceworks.brillonline.com/ entries / encyclopedia-of-women-and-islamic-cultures/cinema-representations-in-commercial-filmsCOM_002068 (accessed on 29 July 2017). 
Film Indonesia. 2013. Data Penonton: 10 Film Indonesia Peringkat Teratas dalam Perolehan Jumlah Penonton pada Tahun 2007-2013 Berdasarkan Tahun Edar Film. Available online: http:/ / filmindonesia.or.id/movie/ viewer/2007-2013\#.Ui6JPG37Qik (accessed on 18 May 2013).

Geertz, Clifford. 1976. The Religion of Java. Chicago: University of Chicago Press.

Haddad, Yvonne. Y. 2007. The Post-9/11 Hijab as Icon. Sociology of Religion 63: 253-67. [CrossRef]

Hall, Stuart. 1997. The work of representation. In Representation: Cultural Representations and Signifying Practice. Edited by Stuart Hall. London, Thousand Oaks and New Delhi: SAGE Publications, pp. 13-64.

Hall, Ronald E. 2003. A note on September eleventh: The Arabization of terrorism. The Social Science Journal 40: 459-64. [CrossRef]

Harian Umum Pelita. 2014. Peserta Umrah Meningkat Satu Juta Jamaah. Harian Umum Pelita, May.

Hasits, Muhammad. 2008. Nonton Ayat-Ayat Cinta, SBY Nangis. Okezone. March 28. Available online: http:/ / news.okezone.com/read/2008/03/28/1/95655/nonton-ayat-ayat-cinta-sby-nangis (accessed on 20 February 2015).

Hassan, Riaz. 2006. Globalisation's Challenge to the Islamic Ummah. Asian Journal of Social Science 34: 311-23. [CrossRef]

Robert W. Hefner, and Patricia Horvatich, eds. 1999. Islam in an Era of Nation-States: Politics and Religious Renewal in Muslim Southeast Asia. Honolulu: University of Hawaii Press.

Heryanto, Ariel. 2014. Identity and Pleasure: The Politics of Indonesian Screen Culture. Singapore: NUS Press.

Hugo, Graeme. 2003. Information, Exploitation and Empowerment: The Case of Indonesian Overseas Workers. Asian and Pacific Migration Journal 12: 439-67. [CrossRef]

Imanda, Tito. 2012. Independent versus Mainstream Islamic Cinema in Indonesia: Religion Using the Market or Vice Versa? In Southeast Asian Independent Cinema: Essays, Documents, Interviews. Edited by Tilman Baumgärtel. TransAsia: Screen Cultures: Hong Kong: Hong Kong University Press.

IRIN. 2009. Indonesia: Tough Times for Returning Labor Migrants. Jakarta: Integrated Regional Information Networks (IRIN).

Jay, Robert R. 1969. Javanese Villagers: Social Relations in Rural Modjokuto. Cambridge: MIT Press.

Jones, Carla. 2010. Images of Desire. Journal of Middle East Women's Studies 6: 91-117. [CrossRef]

Kahn, Joel S. 2015. Foundational Islams: Implications for Dialogue. Arena Magazine 134: 22-26.

Kurnia, Novi. 2014. Women Directors in Post-New Order Indonesia: Making a Film, Making a Difference. Ph.D. Thesis, Flinders University, Bedford Park, Australia.

Laffan, Michael. 2004. An Indonesian community in Cairo: Continuity and Change in a Cosmopolitan Islamic Milieu. Indonesia 77: 1-26.

Lambek, Michael J. 1993. Knowledge and Practice in Mayotte: Local Discourses of Islam, Sorcery and Spirit Possession. Anthropological Horizons; Toronto: University of Toronto Press.

Le Renard, Amelie. 2008. "Only for Women:" Women, the State, and reform in Saudi Arabia. The Middle East Journal 62: 610-29. [CrossRef]

Lücking, Mirjam. 2014. Making 'Arab' One's Own. Muslim Pilgrimage Experiences in Central Java, Indonesia. International Quarterly for Asian Studies 45: 129-52.

Lücking, Mirjam. 2016. Beyond Islam Nusantara and "Arabization": Capitalizing "Arabness" in Madura, East Java. The German Journal on Contemporary Asia 137: 5-24.

Lücking, Mirjam. 2017. Indonesians' and Their Arab World-Guided Mobility among Labour Migrants and Mecca Pilgrims. Ph.D. Thesis, University of Freiburg, Freiburg im Breisgau, Germany. unpublished.

Luqman, A. 2000. Komik Haji: Cara Mabrur naik Haji \& Umroh. Jakarta: Nirmana.

Majalah Tempo. 2015. Ini Bukan Dearabisasi. Majalah Tempo. July 13. Available online: http://majalah.tempo.co/ konten/2015/07/13/LU/148623/Ini-Bukan-Dearabisasi/21/44 (accessed on 16 July 2015).

Mulder, Niels. 1997. Images of Javanese Gender. In Images of Malay-Indonesian Identity. Edited by Michael Hitchcock and Victor T. King. Kuala Lumpur, Oxford and New York: Oxford University Press, pp. 138-47.

Nef Saluz, Claudia. 2007. Islamic Pop Culture in Indonesia: An Anthropological Field Study on Veiling Practices among Students of Gadjah Mada University of Yogyakarta. Arbeitsblatt/Institut für Sozialanthropologie, Universität Bern Nr. 41; Bern: Institut für Sozialanthropologie. 
Newland, Lynda. 2000. Under the Banner of Islam: Moblising Religious Identities in West Java. The Australian Journal of Anthropology 11: 199-222. [CrossRef]

Nuh, Muhammad. 2008. Dakwah di Balik Ketika Cinta Bertasbih. Available online: http://www.eramuslim. $\mathrm{com} /$ berita/silaturrahim/dakwah-di-balik-ketika-cinta-bertasbih.htm\#.VQzzKuHoTcc (accessed on 21 March 2015).

Paramaditha, Intan. 2010. Passing and Conversion Narratives: Ayat-Ayat Cinta and Muslim Performativity in Contemporary Indonesia. Asian Cinema 21: 69-91. [CrossRef]

Rodemeier, Susanne. 2009. Zartes Signal einer Wende. Aktueller arabischer Einfluss auf Java. Südostasien. Zeitschrift für Politik, Kultur, Dialog 4: 52-55.

Rohmaniyah, Inayah, and Mark Woodward. 2012. Wahhabi Perspective on Pluralism and Gender: A Saudi-Indonesian Contrast. In Center for Strategic Communication. Tempe: Arizona State University.

Said, Edward W. 1978. Orientalism, 1st ed. New York: Pantheon Books.

Sakai, Minako. 2012. Preaching to Muslim Youth in Indonesia: The Dakwah Activities of Habiburrahman El Shirazy. Review of Indonesian and Malaysian Affairs 46: 9-31.

Schlehe, Judith, and Eva F. Nisa. 2016. The Meanings of Moderate Islam in Indonesia: Alignments and Dealignments of Azharites. In Southeast Asian Studies at the University of Freiburg. Occasional Paper Series, No. 31; Available online: http:/ / www.southeastasianstudies.uni-freiburg.de/publications/op-series (accessed on 24 August 2016).

Sidani, Yusuf. 2005. Women, Work, and Islam in Arab Societies. Women in Management Review 20: 498-512. [CrossRef]

Silvey, Rachel M. 2004. Transnational domestication: State power and Indonesian migrant women in Saudi Arabia. Political Geography 23: 245-64. [CrossRef]

Silvey, Rachel M. 2006. Consuming the Transnational Family: Indonesian Migrant Domestic Workers to Saudi Arabia. Global Network 6: 1-18. [CrossRef]

Silvey, Rachel M. 2012. Gender, Difference, and Contestation: Economic Geography through the Lens of Transnational Migration. In The Wiley-Blackwell Companion to Economic Geography. Edited by Trevor J. Barnes, Jamie Peck and Eric S. Sheppard. Paperback Edition. Wiley Blackwell Companions to Geography; Chichester: Wiley Blackwell.

Slama, Martin. 2008. Islam Pribumi. Der Islam der Einheimischen, seiner "Arabisierung" und arabische Diasporagemeinschaften in Indonesien. ASEAS—Österreichische Zeitschrift für Südostasienwissenschaften 1: 4-17.

Slama, Martin. 2015. In Between and in the Middle: Multiple Positions of the Hadhramis in Indonesia. Paper Presented at FRIAS Conference, University of Freiburg, Freiburg im Breisgau, Germany, unpublished.

Thimm, Viola. 2015. Die arabische Abaya in Malaysia. Verhandlungen von muslimischen Kleidungspraktiken weiblicher Körperlichkeit, und Modernität. Paideuma 61: 95-116.

Van Bruinessen, Martin. 2013. "Ghazwul fikri" or Arabization? Indonesian Muslim Responses to Globalization. In Dynamics of Southeast Asian Muslims in the Era of Globalization. Edited by Ken Miichi and Omar Farouk. Tokyo: Japan International Cooperation Agency Research Institute, pp. 47-70.

Wahid, Abdurahman. 2005. Right Islam vs. Wrong Islam. Available online: https:/ /www.wsj.com/articles/ SB113590649048834335 (accessed on 24 June 2016).

Wieringa, Saskia. 2006. Islamization in Indonesia: Women Activists' Discourses. Signs: Journal of Women in Culture and Society 32: 1-8. [CrossRef]

Wijoseno, Gagah. 2008. Din Syamsuddin: Lawan Fitna dengan Ayat-Ayat Cinta. Available online: http://news. detik.com/read/2008/04/07/164434/919701/10/din-syamsuddin-lawan-fitna-dengan-ayat-ayat-cinta (accessed on 30 January 2015).

Winarnita, Monika S. 2016. Dancing the Feminine: Gender and Identity Performances by Indonesian Migrant Women. Brighton: Sussex Academic Press.

Woodward, Mark, Inayah Rohmaniyah, Ali Amin, Samsul Ma‘arif, Diana Murtaugh Coleman, and Muhammad Sani Umar. 2012. Ordering What is Right, Forbidding What is Wrong: Two Faces of Hadrami Dakwah in Contemporary Indonesia. Review of Indonesian and Malaysian Affairs 46: 105-46.

Bramantyo, Hanung. 2008. Ayat-Ayat Cinta. Directed by Hanung Bramantyo. South Jakarta: MD Pictures. 
Umam, Chaerul. 2009a. Ketika Cinta Bertasbih 1. Directed by Chaerul Umam. Jakarta: SinemArt.

Umam, Chaerul. 2009b. Ketika Cinta Bertasbih 2. Directed by Chaerul Umam. Jakarta: SinemArt Pictures.

(C) 2017 by the authors. Licensee MDPI, Basel, Switzerland. This article is an open access article distributed under the terms and conditions of the Creative Commons Attribution (CC BY) license (http:/ / creativecommons.org/licenses/by/4.0/). 